Article

\title{
Multiple Resistance of Horseweed to Glyphosate and Paraquat and Its Control with Paraquat and Metribuzin Combinations
}

\author{
Thomas W. Eubank ${ }^{1}$, Vijay K. Nandula ${ }^{2, *}$, Daniel H. Poston ${ }^{3}$ and David R. Shaw ${ }^{4}$ \\ 1 Delta Research and Extension Center, Mississippi State University, 82 Stoneville Road, Stoneville, \\ MS 38776, USA; E-Mail: teubank@drec.msstate.edu \\ 2 Crop Production Systems Research Unit, USDA-ARS, 141 Experiment Station Road, Stoneville, \\ MS 38776, USA \\ 3 Pioneer Hi-Bred International-Southern Business Unit, 700 Blvd. S, SW, Suite 302, Huntsville, \\ AL 35802, USA; E-Mail: dan.poston@pioneer.com \\ 4 Research and Development, Mississippi State University, Starkville, MS 39762, USA; \\ E-Mail: dshaw@research.msstate.edu \\ * Author to whom correspondence should be addressed; E-Mail: vijay.nandula@ars.usda.gov (V.N.); \\ Tel.: +1-662-686-3760; Fax: +1-662-686-7422.
}

Received: 2 November 2012; in revised form: 23 November 2012 / Accepted: 12 December 2012 / Published: 19 December 2012

\begin{abstract}
Greenhouse and field studies were conducted in 2007 and 2008 to investigate possible multiple-resistance of horseweed to paraquat and glyphosate, and to evaluate the effect of the addition of metribuzin to paraquat on control of paraquat-resistant horseweed. Results indicated that the $\mathrm{GR}_{50}$ (herbicide dose required to cause a $50 \%$ reduction in plant growth) value for the susceptible population S102 was $0.066 \mathrm{~kg}$ ae/ha glyphosate, and for the resistant population MDOT was $0.78 \mathrm{~kg} / \mathrm{ha}$ glyphosate. The level of glyphosate resistance for MDOT was 12-fold compared with $\mathrm{S} 102$. The $\mathrm{GR}_{50}$ value for the susceptible population S102 was $0.078 \mathrm{~kg}$ ai/ha paraquat, and for the resistant population MDOT was $0.67 \mathrm{~kg} / \mathrm{ha}$ paraquat. The level of paraquat resistance for MDOT was 9-fold compared to S102, suggesting multiple-resistance to glyphosate and paraquat in the MDOT population. In field studies the addition of metribuzin to paraquat improved horseweed control.
\end{abstract}

Keywords: glyphosate; herbicide resistance; metribuzin; multiple resistance; paraquat; resistance 


\section{Introduction}

Bipyridiliums are a class of herbicides, developed in the 1950s, that are described as photosynthetic inhibitors or cell membrane disruptors. There are currently two compounds classified as bipyridiliums: paraquat and diquat [1]. These herbicides accept electrons in the light reaction cycle of Photosystem I (PSI) that occurs in the chloroplast of most plants [2]. This leads to the formation of hydroxyl radicals. Lipid cell membranes are rapidly degraded by these hydroxyl radicals, which results in the rupture of cell membranes and spilling of cell contents, eventually causing wilting and desiccation of plant tissues $[1,2]$. Paraquat is a non-selective, foliar-applied herbicide that is very effective in controlling many broadleaf and grass weed species, and is labeled for use in many agronomic, vegetable, fruit, and nut crops [1]. Due to its rapid action and effectiveness, paraquat has been utilized as a burndown herbicide to remove weed species prior to planting, as well as a desiccant to facilitate harvesting [3].

In the early to mid 1980's Conyza spp., such as C. canadensis (L.) Cronq., C. sumatrensis (Retz.) E. Walker, C. bonariensis (L.) Cronq. and Erigeron philadelphicus (L.) were all reported resistant to paraquat [4-6]. In most cases the resistance occurred where paraquat had been applied multiple times per growing season for consecutive years in orchards and vineyards [5-7]. Paraquat-resistant horseweed (C. canadensis) was discovered in an orchard in Ontario, Canada, where paraquat had been applied 4 to 5 times per year for a 10-year period, and exhibited resistance levels 25 to 35 times higher than that of susceptible populations [7]. These paraquat-resistant plants were also cross-resistant to diquat [8]. In the United States paraquat-resistant horseweed was first documented in Delaware in 2006 [9] and in 1994 was reported in Mississippi [4]; however, this last case was based only on visual observations and definitive evidence is lacking in the literature. Although the exact mechanism of paraquat resistance in horseweed is unknown, it is generally accepted that a reduction in the movement of paraquat, to the site-of-action in the chloroplast, due to a sequestration mechanism of the paraquat cation caused resistance [9-12]. There are currently 28 weed species that have been documented to be resistant to the bipyridilium herbicides [4].

Conyza species have also been reported resistant to other herbicide modes-of-action, including: Photosystem II inhibitors (PSII), acetolactate synthase inhibitors, glycines, ureas and amides [4,8,13]. Glyphosate-resistant (GR) horseweed has become a major problem across much of North America, and has been documented in more than 20 states across the United States, including Mississippi $[4,13,14]$. Horseweed is the first annual broadleaf weed documented to be resistant to glyphosate worldwide [13]. Similar to paraquat resistance, a reduction in movement of glyphosate to the meristematic regions due to sequestration [15], and, in addition, reduced translocation [16,17] were reported as the primary mechanisms for glyphosate resistance in horseweed. These findings, although from different studies, suggest that horseweed has the capacity to effectively reduce the movement of both glyphosate and paraquat within the plant. This raises the possibility of development of resistance to both glyphosate and paraquat in the same horseweed population. Multiple resistance, generally referred to as resistance in a weed population to two or more herbicides with unique mechanisms of action, to both glyphosate and paraquat has been previously reported only in rigid ryegrass (Lolium rigidum Gaud.) [18].

Herbicide-resistant horseweed is a serious concern. GR horseweed has necessitated research to find alternative control measures for this troublesome weed [3,19-21]. Previous research [3] concluded that 
a horseweed population near Leland, MS, was not effectively controlled with either $0.86 \mathrm{~kg}$ ae/ha glyphosate (60 to $65 \%$ ) or $0.84 \mathrm{~kg}$ ai/ha paraquat (55 to $63 \%$ ) at 4 weeks after treatment (WAT). Interestingly, the addition of metribuzin, a PS II inhibitor, to paraquat improved the level of horseweed control over paraquat alone [3]. Research investigating alternative methods of control for potential multiple-resistant horseweed is much desired.

Therefore, the objectives of this study were to determine if multiple resistance to glyphosate and paraquat exists in a horseweed population near Leland, MS, and to evaluate the influence of addition of metribuzin to paraquat on control of paraquat-resistant horseweed.

\section{Results and Discussion}

\subsection{Glyphosate and Paraquat Multiple Resistance Estimation}

Glyphosate dose response results results showed that $\mathrm{GR}_{50}$ value for the glyphosate-susceptible S102 population was $0.066 \mathrm{~kg} / \mathrm{ha}$ and that for the -resistant MDOT population was $0.78 \mathrm{~kg} / \mathrm{ha}$ (Figure 1). The level of glyphosate resistance for MDOT was 12-fold when compared with S102. This level of glyphosate resistance is similar to those reported previously [13,14]. At 3 WAT, a 40 to $60 \%$ reduction in horseweed biomass was realized at the three lowest glyphosate rates $(0.025,0.05$ and $0.1 \mathrm{~kg} / \mathrm{ha}$ ) for the S102 population, whereas MDOT averaged a 3\% increase in biomass across these same rates (Figure 1). Biomass for the MDOT population was reduced roughly $50 \%$ with the normal field use rate of $0.84 \mathrm{~kg} / \mathrm{ha}$ glyphosate, while $\mathrm{S} 102$ was completely controlled at the same rate (Figure 1).

Figure 1. Glyphosate dose response on above ground shoot growth of resistant (MDOT) and susceptible (S102) horseweed populations. GR $_{50}$ (herbicide dose required to reduce plant growth by 50\%) values for MDOT and S102 populations were 0.78 and $0.066 \mathrm{~kg}$ ae/ha glyphosate, respectively.

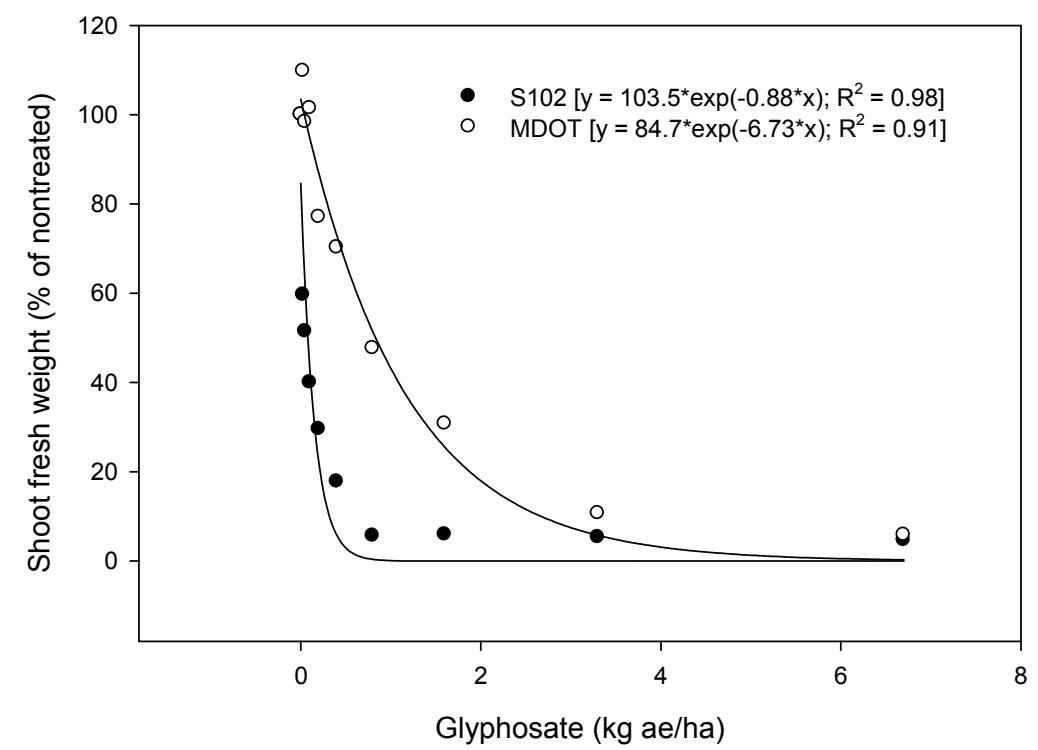


The $\mathrm{GR}_{50}$ values of paraquat for $\mathrm{S} 102$ was $0.078 \mathrm{~kg} / \mathrm{ha}$ and that for MDOT was $0.67 \mathrm{~kg} / \mathrm{ha}$ (Figure 2). The level of paraquat resistance for MDOT was 9-fold when compared with S102. This level of paraquat resistance is much lower than the previously reported 22-fold [9] and 35-fold [7] cases of horseweed, and the 100-fold case of Conyza bonariensis [12]. Horseweed biomass for the MDOT population increased an average of $7 \%$ across the three lowest rates of paraquat $(0.017,0.034$ and $0.07 \mathrm{~kg} / \mathrm{ha}$ ), while S102 biomass decreased from 15 to $46 \%$ (Figure 2). Biomass for the S102 population was reduced more than $90 \%$ at the normal field use rate of $0.84 \mathrm{~kg} / \mathrm{ha}$ paraquat, while MDOT biomass was reduced only 57\% (Figure 2).

Figure 2. Paraquat dose response on above ground shoot growth of resistant (MDOT) and susceptible (S102) horseweed populations. GR $_{50}$ (herbicide dose required to reduce plant growth by 50\%) values for MDOT and S102 populations were 0.67 and $0.078 \mathrm{~kg}$ ai/ha paraquat, respectively.

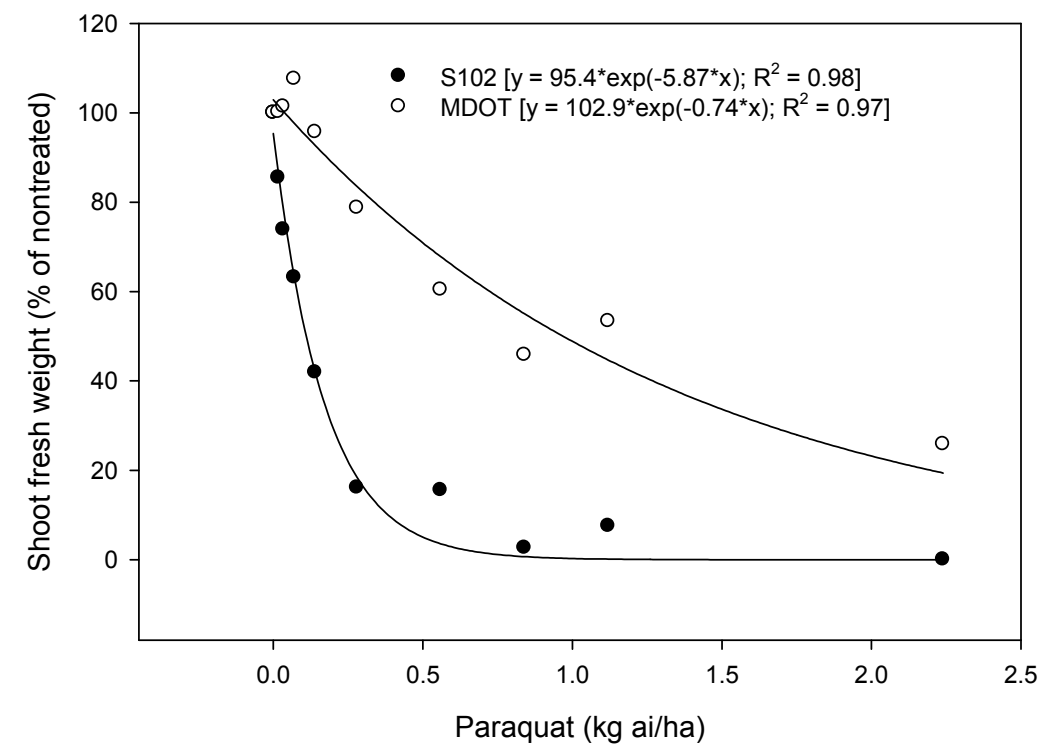

These data suggest that multiple-resistance to glyphosate and paraquat exists in the MDOT horseweed population from Mississippi. This is the first broadleaf weed species reported as exhibiting multiple-resistance to these two unique herbicide chemistries, and the first species appear in an agronomic row crop situation. Multiple-resistance to both glyphosate and paraquat has only been previously reported in rigid ryegrass [18]. While the mechanism of resistance to glyphosate and/or paraquat in the MDOT population has neither been characterized nor is this the focus of this paper, it is interesting to speculate given the multiple resistance finding above. If resistance is due to sequestration, it is likely that resistance to glyphosate or paraquat by this mechanism has led to resistance to the other herbicide. Conversely, if it is not sequestration, it is likely that resistance to glyphosate and paraquat have occurred independent of each other in no particular order. 


\subsection{Paraquat and Metribuzin Influence on Horseweed Growth and Soybean Yield}

A year by horseweed size interaction necessitated presentation of data separated by year and horseweed size (Tables 1 and 2). There were no differences between the 14 and 28 DAT control ratings (14 DAT data not presented). Lack of differences between the two observations is likely due to the rapid action of paraquat with visible injury being observed within a matter of days. Paraquat alone at $0.56 \mathrm{~kg} / \mathrm{ha}$ provided the lowest level of control (72\%) of 10-cm horseweed in 2007 (Table 1). Increasing paraquat rate to 0.84 or $1.12 \mathrm{~kg} / \mathrm{ha}$ improved horseweed control to 80 and $88 \%$, respectively. All levels of paraquat + all levels of metribuzin gave at least $93 \%$ control of $10-\mathrm{cm}$ horseweed in 2007. Overall, control of 10-cm horseweed was poor in 2008 compared to 2007. In 2008, the lowest rate of paraquat alone controlled horseweed only $30 \%$, while the highest rate of paraquat alone enhanced horseweed control to merely 50\%. Horseweed control in 2008 was improved only with the highest rate of paraquat + all combinations of metribuzin and $0.84 \mathrm{~kg} / \mathrm{ha}$ paraquat $+0.4 \mathrm{~kg} / \mathrm{ha}$ metribuzin compared to $1.12 \mathrm{~kg} / \mathrm{ha}$ paraquat alone. The reduced levels of control in 2008 compared to 2007 may have been due to low air temperatures on the day of application of paraquat and the following 24 hours $\left(13\right.$ and $16{ }^{\circ} \mathrm{C}$ in 2007 and 8 and $8{ }^{\circ} \mathrm{C}$ in 2008 , respectively), thereby, slowing the movement of paraquat within the treated plants. Low air temperatures have been reported to reduce weed control with paraquat. Resistant Hordeum leporinum Link. and H. glaucum Steud. plants did not respond to applications of paraquat at $15{ }^{\circ} \mathrm{C}$, but were effectively controlled at $30{ }^{\circ} \mathrm{C}$ [22]. Earlier research has also suggested that lower air temperatures reduced basipetal translocation of paraquat in Hordeum. spp. and glufosinate in Raphanus raphanistrum [22,23].

Visual control ratings of $15-\mathrm{cm}$ horseweed were lowest with $0.56 \mathrm{~kg} / \mathrm{ha}$ paraquat, at only $60 \%$ and 53\% control in 2007 and 2008, respectively, and were lower than all other treatments (Table 2). Increasing paraquat rate to $0.84 \mathrm{~kg} /$ ha improved horseweed control to $73 \%$ and $70 \%$ in 2007 and 2008 , respectively. In 2007, the addition of metribuzin to paraquat did not improve control of $15-\mathrm{cm}$ horseweed over the highest rate of paraquat alone with the exception of $0.84 \mathrm{~kg} / \mathrm{ha}$ paraquat + $0.4 \mathrm{~kg} / \mathrm{ha}$ metribuzin or $1.12 \mathrm{~kg} / \mathrm{ha}$ paraquat $+0.2 \mathrm{~kg} / \mathrm{ha}$ metribuzin. The addition of $0.2 \mathrm{~kg} / \mathrm{ha}$ metribuzin to $0.56 \mathrm{~kg} / \mathrm{ha}$ paraquat improved control of $15-\mathrm{cm}$ horseweed over the highest rate of paraquat alone in 2008. The medium and highest rate of paraquat + all levels of metribuzin gave at least $93 \%$ control of $15-\mathrm{cm}$ horseweed in 2008. These data suggest that the addition of a PSII herbicide, such as metribuzin, to paraquat can improve control of horseweed. Similar findings were reported previously [24], where paraquat efficacy of quackgrass (Agropyron repens L. Beauv.) was improved with the addition of simazine; however, these results conflict with other findings where $0.84 \mathrm{~kg} /$ ha paraquat $+1.12 \mathrm{~kg}$ ha prometryn only provided $58 \%$ control of GR horseweed of unknown size [19]. 
Table 1. Horseweed (10-cm) control, plant density, and biomass 28 day after treatment, and soybean yield near Stoneville, Mississippi ${ }^{\text {a }}$

\begin{tabular}{|c|c|c|c|c|c|c|c|c|c|}
\hline \multirow[b]{2}{*}{ Treatment } & \multirow[b]{2}{*}{$\begin{array}{c}\text { Rate } \\
\text { kg ai/ha }\end{array}$} & \multicolumn{4}{|c|}{2007} & \multicolumn{4}{|c|}{2008} \\
\hline & & $\begin{array}{c}\text { Control } \\
28 \mathrm{DAT} \\
-\% \\
\end{array}$ & $\begin{array}{c}\text { Density } \\
28 \text { DAT } \\
\text { plants } / \mathbf{m}^{2}\end{array}$ & $\begin{array}{c}\text { Biomass } \\
28 \text { DAT } \\
\text { g/m } \mathbf{m}^{2} \\
\end{array}$ & $\begin{array}{l}\text { Yield } \\
\mathrm{kg} / \mathrm{ha}\end{array}$ & $\begin{array}{c}\text { Control } \\
28 \text { DAT } \\
-\% \\
\end{array}$ & $\begin{array}{c}\text { Density } \\
28 \text { DAT } \\
\text { plants } / \mathbf{m}^{2}\end{array}$ & $\begin{array}{c}\text { Biomass } \\
28 \text { DAT } \\
\text { g/m } / \mathbf{m}^{2} \\
\end{array}$ & $\begin{array}{l}\text { Yield } \\
\text { kg/ha }\end{array}$ \\
\hline Nontreated & & 0 & 48 & 360 & 360 & 0 & 30 & 110 & 740 \\
\hline Paraquat ${ }^{b}$ & 0.56 & 72 & 73 & 150 & 540 & 30 & 65 & 360 & 1200 \\
\hline Paraquat & 0.84 & 80 & 38 & 90 & 360 & 40 & 71 & 430 & 1250 \\
\hline Paraquat & 1.12 & 88 & 23 & 40 & 740 & 50 & 59 & 470 & 1370 \\
\hline Paraquat + Metribuzin & $0.56+0.1$ & 93 & 6 & 10 & 1220 & 40 & 89 & 290 & 1340 \\
\hline Paraquat + Metribuzin & $0.56+0.2$ & 93 & 5 & 10 & 1490 & 48 & 37 & 180 & 1570 \\
\hline Paraquat + Metribuzin & $0.56+0.4$ & 98 & 2 & 5 & 1490 & 50 & 47 & 290 & 1400 \\
\hline Paraquat + Metribuzin & $0.84+0.1$ & 93 & 4 & 10 & 1290 & 48 & 35 & 270 & 1310 \\
\hline Paraquat + Metribuzin & $0.84+0.2$ & 100 & 1 & 0 & 1900 & 53 & 25 & 200 & 1520 \\
\hline Paraquat + Metribuzin & $0.84+0.4$ & 100 & 0 & 0 & 1990 & 78 & 16 & 140 & 1440 \\
\hline Paraquat + Metribuzin & $1.12+0.1$ & 95 & 1 & 5 & 1870 & 73 & 16 & 50 & 1360 \\
\hline Paraquat + Metribuzin & $1.12+0.2$ & 98 & 0 & 1 & 2060 & 78 & 13 & 90 & 1300 \\
\hline Paraquat + Metribuzin & $1.12+0.4$ & 100 & 0 & 0 & 1680 & 83 & 3 & 10 & 1250 \\
\hline $\operatorname{LSD}(0.05)$ & & 7 & 27 & 105 & 650 & 18 & 45 & 240 & 720 \\
\hline
\end{tabular}


Table 2. Horseweed $(15-\mathrm{cm})$ control, plant density, and biomass 28 day after treatment, and soybean yield in Stoneville, Mississippi ${ }^{\text {a }}$

\begin{tabular}{|c|c|c|c|c|c|c|c|c|c|}
\hline \multirow[b]{2}{*}{ Treatment } & \multirow[b]{2}{*}{$\begin{array}{c}\text { Rate } \\
\text { kg ai/ha }\end{array}$} & \multicolumn{4}{|c|}{2007} & \multicolumn{4}{|c|}{2008} \\
\hline & & $\begin{array}{c}\text { Control } \\
28 \text { DAT } \\
-\%- \\
\end{array}$ & $\begin{array}{c}\text { Density } \\
28 \text { DAT } \\
\text { plants/m² }\end{array}$ & $\begin{array}{c}\text { Biomass } \\
28 \text { DAT } \\
\text { g/m } / \mathrm{m}^{2} \\
\end{array}$ & $\begin{array}{l}\text { Yield } \\
\mathrm{kg} / \mathrm{ha}\end{array}$ & $\begin{array}{c}\text { Control } \\
28 \text { DAT } \\
-\% \\
\end{array}$ & $\begin{array}{c}\text { Density } \\
28 \text { DAT } \\
\text { plants/m² }\end{array}$ & $\begin{array}{c}\text { Biomass } \\
28 \text { DAT } \\
\text { g/m } / \mathrm{m}^{2} \\
\end{array}$ & $\begin{array}{c}\text { Yield } \\
\mathrm{kg} / \mathrm{ha}\end{array}$ \\
\hline Nontreated & & 0 & 44 & 1260 & 160 & 0 & 59 & 450 & 1140 \\
\hline Paraquat ${ }^{b}$ & 0.56 & 60 & 23 & 110 & 1230 & 53 & 46 & 420 & 1520 \\
\hline Paraquat & 0.84 & 73 & 17 & 130 & 990 & 70 & 35 & 240 & 1580 \\
\hline Paraquat & 1.12 & 90 & 9 & 70 & 1860 & 70 & 37 & 240 & 1410 \\
\hline Paraquat + Metribuzin & $0.56+0.1$ & 85 & 16 & 50 & 1680 & 78 & 19 & 80 & 1560 \\
\hline Paraquat + Metribuzin & $0.56+0.2$ & 93 & 3 & 10 & 1960 & 85 & 10 & 80 & 1620 \\
\hline Paraquat + Metribuzin & $0.56+0.4$ & 88 & 17 & 80 & 1710 & 80 & 24 & 150 & 1610 \\
\hline Paraquat + Metribuzin & $0.84+0.1$ & 90 & 8 & 30 & 2240 & 93 & 14 & 110 & 1470 \\
\hline Paraquat + Metribuzin & $0.84+0.2$ & 95 & 4 & 10 & 2270 & 95 & 7 & 120 & 1610 \\
\hline Paraquat + Metribuzin & $0.84+0.4$ & 100 & 0 & 0 & 2340 & 95 & 2 & 10 & 1580 \\
\hline Paraquat + Metribuzin & $1.12+0.1$ & 98 & 1 & 30 & 2410 & 95 & 8 & 50 & 1550 \\
\hline Paraquat + Metribuzin & $1.12+0.2$ & 100 & 0 & 0 & 2460 & 98 & 6 & 80 & 1630 \\
\hline Paraquat + Metribuzin & $1.12+0.4$ & 98 & 5 & 10 & 1940 & 98 & 1 & 10 & 1750 \\
\hline $\operatorname{LSD}(0.05)$ & & 9 & 21 & 240 & 660 & 14 & 32 & 240 & 720 \\
\hline
\end{tabular}


Horseweed plant densities in the nontreated, at the $10-\mathrm{cm}$ growth stage, were 48 and 30 plants $/ \mathrm{m}^{2}$ in 2007 and 2008, respectively (Table 1). Horseweed plant densities were not reduced across all levels of the paraquat alone treatments compared to the nontreated in either year. The lowest rate of paraquat alone $(0.56 \mathrm{~kg} / \mathrm{ha})$ resulted in a net increase in horseweed densities of 52 and $117 \%$ in 2007 and 2008, respectively. This was likely due to the removal of competition to horseweed from other weeds such as henbit (Lamium amplexicaule L.), common chickweed [Stellaria media (L.) Vill.], and annual bluegrass (Poа аппиа L.) within treated plots, allowing emergence of new horseweed plants. Also, the addition of metribuzin may have prevented emergence of horseweed after application compared to paraquat alone and may have confounded density results. The addition of metribuzin to paraquat reduced horseweed populations compared to the nontreated, by at least $88 \%$. There was no reduction in horseweed population across all herbicide treatments in 2008 . This is likely attributed to the reduced levels of horseweed control in 2008 , as observed previously.

Horseweed plant densities in the nontreated plots, at the $15-\mathrm{cm}$ growth stage, were 44 and 59 plants $/ \mathrm{m}^{2}$ in 2007 and 2008, respectively (Table 2). All herbicide treatments reduced horseweed densities compared to the nontreated in 2007. Paraquat alone treatments reduced horseweed densities from $48 \%$ to $80 \%$, while the addition of metribuzin to 0.84 and $1.12 \mathrm{~kg} /$ ha levels of paraquat reduced horseweed densities from $82 \%$ to $100 \%$. Paraquat alone did not reduce horseweed densities compared to the nontreated in 2008; however, all paraquat + metribuzin combinations reduced horseweed populations compared to the nontreated in 2008.

Horseweed biomass in the nontreated plots, at the $10-\mathrm{cm}$ growth stage, was 360 and $110 \mathrm{~g} / \mathrm{m}^{2}$ in 2007 and 2008, respectively (Table 1). All treatments effectively reduced horseweed biomass compared to the nontreated in 2007. Paraquat alone reduced horseweed biomass from $57 \%$ to $88 \%$. The addition of metribuzin to paraquat reduced biomass $98 \%$ to $100 \%$; however, these treatments were not better than 0.84 and $1.12 \mathrm{~kg} /$ ha paraquat alone. No herbicide treatments reduced horseweed biomass compared to the nontreated in 2008. Several treatments, including all levels of paraquat alone, actually increased horseweed biomass numbers from $124 \%$ to $427 \%$. This is likely attributed to the reduced levels of horseweed control in 2008, as stated previously, and the removal of other weed species, allowing remaining horseweed plants to proliferate.

Horseweed biomass in the nontreated, at the 15-cm growth stage, was 1260 and $1140 \mathrm{~g} / \mathrm{m}^{2}$ in 2007 and 2008, respectively (Table 2). All herbicide treatments reduced horseweed biomass from $90 \%$ to $100 \%$ compared to the nontreated in 2007 . There were no differences between herbicide treatments in 2007. Paraquat alone treatments did not reduce horseweed biomass compared to the nontreated in 2008. All paraquat + metribuzin treatments improved the reduction in horseweed biomass from $66 \%$ to $99 \%$ compared to the nontreated.

Soybean yields following treatments targeted at 10 -cm horseweed in 2007 were $540 \mathrm{~kg} / \mathrm{ha}$ with $0.56 \mathrm{~kg} / \mathrm{ha}$ paraquat, $360 \mathrm{~kg} / \mathrm{ha}$ with $0.84 \mathrm{~kg} / \mathrm{ha}$ paraquat, and $740 \mathrm{~kg} / \mathrm{ha}$ with $1.12 \mathrm{~kg} / \mathrm{ha}$ paraquat, and were not different from $360 \mathrm{~kg} /$ ha from the nontreated plots (Table 1). The addition of metribuzin to paraquat improved soybean yields from 1220 to $2060 \mathrm{~kg} / \mathrm{ha}$ compared to the nontreated. Soybean yields with the lowest rate of metribuzin +0.56 and $0.84 \mathrm{~kg} / \mathrm{ha}$ paraquat at 1220 and $1290 \mathrm{~kg} / \mathrm{ha}$, respectively, and were the only treatments comparable to the treatments providing yield with the highest rate of paraquat alone at $740 \mathrm{~kg} / \mathrm{ha}$ in 2007 . There were no differences in soybean yield between the herbicide and the nontreated treatments in 2008 . 
Soybean yields following treatments targeted at 15 -cm horseweed in 2007 were $1230 \mathrm{~kg} / \mathrm{ha}$ with $0.56 \mathrm{~kg} / \mathrm{ha}$ paraquat, $990 \mathrm{~kg} / \mathrm{ha}$ with $0.84 \mathrm{~kg} / \mathrm{ha}$ paraquat, and $1860 \mathrm{~kg} / \mathrm{ha}$ with $1.12 \mathrm{~kg} / \mathrm{ha}$ paraquat, and were considerably higher than the nontreated yield of $160 \mathrm{~kg} / \mathrm{ha}$ (Table 2). The addition of metribuzin to paraquat did not improve soybean yields compared to $1.12 \mathrm{~kg} / \mathrm{ha}$ paraquat alone but were higher than $0.84 \mathrm{~kg} / \mathrm{ha}$ paraquat. There were no differences in soybean yield across treatments targeting $15-\mathrm{cm}$ horseweed in 2008 , as with $10-\mathrm{cm}$ horseweed. This was likely due to below-average rainfall in the months of June and July of 2008 (data not shown) and seed rot due to excessive rainfall in conjunction with Hurricane Gustav two weeks prior to soybean harvest.

The herbicide treatments of paraquat alone at 0.56 or $0.84 \mathrm{~kg} /$ ha provided among the lowest levels of horseweed control for either growth stage evaluated each year. The highest rate of paraquat, $1.12 \mathrm{~kg} / \mathrm{ha},+0.1,0.2$, or $0.4 \mathrm{~kg} / \mathrm{ha}$ metribuzin gave the highest level of horseweed control each year. In our studies, paraquat alone did not reduce horseweed densities at the 10-cm application timing either year, or the $15-\mathrm{cm}$ timing in 2008 compared to the nontreated, whereas the addition of metribuzin to paraquat reduced horseweed densities at the 10-cm application timing in 2007 and the $15-\mathrm{cm}$ timing both years. All treatments reduced horseweed biomass in 2007; however, only the addition of metribuzin to paraquat reduced horseweed biomass at the $15-\mathrm{cm}$ application timing in 2008. These findings suggest that the combination of paraquat + metribuzin may be additive or possibly synergistic and improve control of paraquat-resistant horseweed. Statistical analysis for the presence of synergism was not conducted in these studies due to non-inclusion of metribuzin alone treatments. The synergistic effects of paraquat + PS II inhibitors have been well documented [24-26]; however, little research has been done to evaluate these chemistries on the control of horseweed. The addition of metribuzin to paraquat controlled $4-$ to $6-\mathrm{cm}$ horseweed greater than $95 \%$ in no-till soybean [27]; however, a paraquat alone treatment was not included for comparison in this study and several other treatments containing paraquat gave similar results.

\section{Experimental Section}

\subsection{Multiple Resistance Study}

Greenhouse studies were conducted to investigate suspected multiple resistance of horseweed to glyphosate and paraquat. Mature seed from a suspected resistant horseweed population (MDOT) were

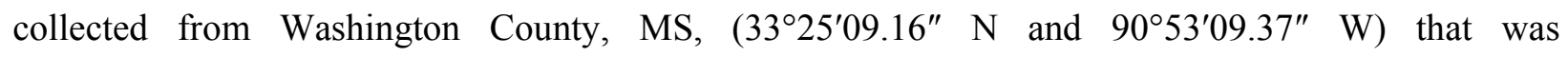
unsuccessfully controlled by $0.84 \mathrm{~kg} /$ ha paraquat and at least two applications of $0.84 \mathrm{~kg} / \mathrm{ha}$ glyphosate in 2007. Cropping history for the MDOT population was preceded by at least five consecutive years of no-till GR soybean (Glycine max (L.) Merr.), indicating exposure to at least two glyphosate applications per growing season. Paraquat exposure history of the MDOT population is not available prior to 2007. A susceptible horseweed population (S102) from Coahoma County, MS (34'12'07.18" $\mathrm{N}$ and $90^{\circ} 32^{\prime} 09.70^{\prime \prime} \mathrm{W}$ ), was included for comparison. Horseweed seeds were surface planted into separate $25 \times 25 \times 6 \mathrm{~cm}$ trays containing Jiffy mix potting media (Jiffy Products of America Inc., Lorain, OH, USA). Trays were subirrigated with distilled water and placed in a growth chamber at $24 / 18{ }^{\circ} \mathrm{C}$ day/night temperatures with supplemental lighting set to a 14 -h photoperiod. When emerged horseweed plants attained at least 3 true leaves in growth, individual plants were transplanted to $10-\mathrm{cm}$ 
wide $\times 15-\mathrm{cm}$ deep pots. Pots were then transferred to a greenhouse with natural light supplemented with sodium vapor lamps $\left(300 \mu \mathrm{mol} / \mathrm{m}^{2} / \mathrm{s}\right)$ set to a 14 -h photoperiod and $25 / 15^{\circ} \mathrm{C}\left( \pm 3{ }^{\circ} \mathrm{C}\right)$ day/night temperature. Plants were sub-irrigated and fertilized (Miracle-Gro, The Scotts Company LLC, Marysville, OH, USA) as needed.

In preliminary resistance screening studies, several MDOT horseweed plants, 10 to $15 \mathrm{~cm}$ in diam that corresponded to approximately 35 to 40 leaves per plant, were treated with a $0.84 \mathrm{~kg} / \mathrm{ha}$ rate of glyphosate (potassium salt, Roundup WeatherMAX ${ }^{\circledR}$, Monsanto Company, St. Louis, MO, USA) (data not shown). Plants that survived 3 WAT were allowed to grow and randomly cross with each other to produce the second generation seed. Additional screening experiments indicated that the second generation plants survived a glyphosate treatment of $0.84 \mathrm{~kg} \mathrm{ha}^{-1}$ (data not shown). This second generation seed was used in all subsequent studies. Similarly, a second generation seed from MDOT horseweed plants that survived a rate of $0.56 \mathrm{~kg} / \mathrm{ha}$ paraquat (Gramoxone Inteon ${ }^{\circledR}$, Syngenta Crop Protection, Greensboro, NC, USA) was generated. Herbicide treatments were initiated when plants reached the above described growth stage. Treatments included: potassium salt of glyphosate at 0.025 , $0.05,0.1,0.2,0.4,0.8,1.6,3.3$, and $6.7 \mathrm{~kg} / \mathrm{ha}$; paraquat at $0.02,0.03,0.07,0.14,0.28,0.56,0.84,1.12$, and $2.24 \mathrm{~kg} / \mathrm{ha}$; and a nontreated control. Paraquat treatments included a non-ionic surfactant (NIS) (Induce $^{\circledR}$, Helena Chemical Co., Collierville, TN, USA) at $0.5 \% \mathrm{v} / \mathrm{v}$. An adjuvant was included in the commercial glyphosate formulation by the manufacturer. Treatments were applied using an indoor spray chamber equipped with an air-pressurized flat-fan nozzle (8002E, Teejet Technologies, Wheaton, IL, USA) calibrated to deliver a spray volume of $140 \mathrm{~L} / \mathrm{ha}$ at a pressure of $220 \mathrm{kPa}$. After treatment, plants were returned to the greenhouse. Horseweed biomass was collected at 3 WAT by harvesting the above ground plant tissue and recorded as fresh weight. Shoot fresh weights were expressed as a percent of the nontreated control for each population by individual replication.

Experimental design was a randomized complete block design with four replications per treatment within each population. Each experiment was conducted three times. All data were subjected to ANOVA using the PROCMIXED procedure in SAS (SAS Institute Inc., Cary, NC, USA) with trial as a random variable. Means were separated using Fisher's Protected LSD test at alpha $\leq 0.05$. An exponential decay model, of the form:

$$
Y=y 0+a \times \exp (-b \times x)
$$

was used to define fresh weight reduction $(Y)$ as a function of the herbicide rate $(x)$ with SigmaPlot software (version 10.0, Systat Software, Inc., San Jose, CA, USA); $y 0$ and $a$ are constants and $b$ is the slope of the response curve. $\mathrm{GR}_{50}$ (herbicide rate required to cause $50 \%$ reduction in horseweed growth) values of glyphosate and paraquat for the two populations were calculated accordingly.

\subsection{Paraquat and Metribuzin Study}

Field studies were conducted in 2007 and 2008 to determine if the addition of metribuzin to paraquat improved the control of paraquat-resistant horseweed. Plots were established near the Delta

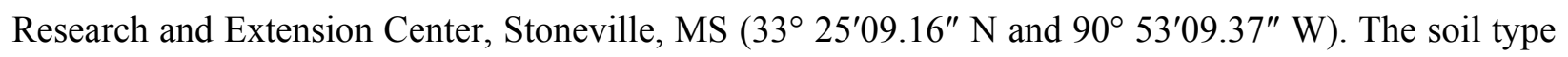
was a Dundee very fine sandy loam (fine-silty, mixed, active, thermic Typic Endoaqualfs) with a $\mathrm{pH}$ of 6.1 and organic matter content of $1.2 \%$. Plots were established following five consecutive years of 
no-tillage GR soybean and were naturally infested with horseweed exhibiting resistance to glyphosate and paraquat. The experimental design was a split-plot design with a factorial arrangement of treatments and four replications in a randomized complete block. Split-plot design had one plot being treated when horseweed averaged $10-\mathrm{cm}$ in height and the second plot treated when horseweed averaged $15-\mathrm{cm}$ in height. Plots were $3 \times 12 \mathrm{~m}$, and herbicide treatments were applied with a tractor-mounted compressed-air sprayer calibrated to deliver $140 \mathrm{~L} / \mathrm{ha}$ at a pressure of $207 \mathrm{kPa}$ using flat fan nozzles (H XR 11002VS, Teejet Technologies). Treatments were applied to 10-cm horseweed on February 28, 2007 and March 24, 2008 and to 15-cm horseweed on March 29, 2007 and May 9, 2008. Herbicide treatments included: paraquat at $0.56,0.84$, and $1.12 \mathrm{~kg} / \mathrm{ha}$ alone and in combination with metribuzin (Sencor ${ }^{\circledR}$, Bayer CropScience, Research Triangle Park, NC, USA) at 0.1, 0.2 and 0.4 $\mathrm{kg}$ ai/ha. A nontreated control was also included for comparison of soybean yields. All treatments were applied as broadcast foliar-applied treatments and included a NIS at $0.5 \% \mathrm{v} / \mathrm{v}$. Visual control ratings were determined using a 0 to 100 scale ( 0 , no control; 100 , complete control) and were measured at 14 and 28 days after treatment (DAT). Horseweed density and biomass from $2 \mathrm{~m}^{2}$ quadrats were recorded at planting or approximately 28 DAT. Horseweed biomass was obtained by harvesting the above ground tissue and extrapolated to $\mathrm{g} / \mathrm{m}^{2}$. The soybean variety Pioneer 94B73 soybean was seeded on April 30, 2007 and NK S43-B1 soybean was seeded on May 9, 2008. Soybean was planted with a seven-row planter on $38-\mathrm{cm}$ row spacing at a seeding rate of $13 \mathrm{seed} / \mathrm{m}$ of row. No additional at-planting burndown applications were applied. Horseweed was allowed to compete with soybean for approximately 2 wk after planting (WAP) before in-season herbicides were applied. For in-season weed management, all plots received POST applications of $0.84 \mathrm{~kg} / \mathrm{ha}$ glyphosate $+1.26 \mathrm{~kg}$ ai $/ \mathrm{ha}$ $S$-metolachlor (Sequence ${ }^{\circledR}$, Syngenta Crop Protection) and $0.84 \mathrm{~kg} / \mathrm{ha}$ glyphosate alone at 2 and 7 WAP, respectively. The center five rows of the seven-row plots were harvested with a research small-plot combine. Soybean yields and moisture were recorded and moisture was adjusted to $13 \%$. All data were subjected to ANOVA using the general linear model in SAS. Means were separated using Fisher's Protected LSD test at alpha $\leq 0.05$.

\section{Conclusions}

Horseweed exhibiting multiple-resistance to glyphosate and paraquat has been confirmed in Mississippi. In our study, the MDOT horseweed population survived normal use rates of glyphosate and paraquat. This is the first broadleaf weed species reported as exhibiting multiple-resistance to these chemistries, and the first such species overall to appear in an agronomic row crop situation. Tankmixing metribuzin with paraquat improved the control of this troublesome weed.

\section{References}

1. Senseman, S.A. Herbicide Handbook, 9th ed.; Weed Science Society of America: Lawrence, KS, USA, 2009.

2. Devine, M.D.; Duke, S.O.; Fedtke, C. Other herbicidal interactions with photosynthesis. In Physiology of Herbicide Action; Prentice Hall: Englewood Cliffs, NJ, USA, 1993; pp. 141-166. 
3. Eubank, T.W.; Poston, D.H.; Nandula, V.K.; Koger, C.H.; Shaw, D.R.; Reynolds, D.B. Glyphosate-resistant horseweed (Conyza canadensis) control using glyphosate-, paraquat-, and glufosinate-based herbicide programs. Weed Technol. 2008, 22, 16-21.

4. Heap, I. Herbicide Resistant Weeds. Weed Science Society of America. Available online: http://www.weedscience.org/ (accessed on 1 November 2012).

5. Kato, A.; Okuda, Y. Paraquat resistance in Erigeron canadensis. Weed Res. 1983, 28, 54-56.

6. Watanabe, Y.; Honma, T.; Ito, K.; Miyrahara, M. Paraquat resistance in Erigeron philadelphicus L. Weed Res. 1982, 27, 49-54.

7. Smisek, A.; Doucet, C.; Jones, M.; Weaver, S. Paraquat resistance in horseweed (Conyza canadensis) and Virginia pepperweed (Lepidium virginicum) from Essex County, Ontario. Weed Sci. 1998, 46, 200-204.

8. Weaver, S.; Downs, M.; Neufeld, B. Response of paraquat-resistant and -susceptible horseweed (Conyza canadensis) to diquat, linuron, and oxyfluorfen. Weed Sci. 2004, 52, 549-553.

9. VanGessel, M.J.; Scott, B.A.; Johnson, Q.R. Paraquat-resistant horseweed identified in the Mid-Atlantic States. Crop Manag. 2006, doi:1094/cm-2006-0420-01-RS.

10. Fuerst, E.P.; Nakatani, H.Y.; Dodge, A.D.; Penner, D.; Arntzen, C.J. Paraquat resistance in Conyza. Plant Physiol. 1985, 77, 984-989.

11. Jori, B.; Soos, V.; Szego, D.; Paldi, E.; Szigeti, Z.; Racz, I.; Lasztity, D. Role of transporters in paraquat resistance of horseweed Conyza canadensis (L.) Cronq. Pestic. Biochem. Physiol. 2007, 88, 57-65.

12. Norman, M.A.; Fuerst, E.P.; Smeda, R.J.; Vaughn, K.C. Evaluation of paraquat resistance mechanisms of Conyza. Pestic. Biochem. Physiol. 1993, 46, 236-249.

13. VanGessel, M.J. Glyphosate-resistant horseweed from Delaware. Weed Sci. 2001, 49, 703-705.

14. Koger, C.H.; Poston, D.H.; Hayes, R.M.; Montgomery, R.F. Glyphosate-resistant horseweed (Conyza canadensis) in Mississippi. Weed Technol. 2004, 18, 820-825.

15. Ge, X.; d'Avignon, D.A.; Ackerman, J.J.; Sammons, R.D. Rapid vacuolar sequestration: The horseweed glyphosate resistance mechanism. Pest Manag. Sci. 2010, doi:10.1002/ps.1911.

16. Feng, P.C.; Tran, M.; Chiu, T.; Sammons, R.D.; Heck, G.R.; CaJacob, C.A. Investigation into glyphosate-resistant horseweed (Conyza canadensis): Retention, uptake, translocation, and metabolism. Weed Sci. 2004, 52, 498-505.

17. Koger, C.H.; Reddy, K.N. Role of absorption and translocation in the mechanism of glyphosate resistance in horseweed (Conyza canadensis). Weed Sci. 2005, 53, 84-89.

18. Yu, Q.; Cairns, A.; Powles, S.B. Glyphosate, paraquat and ACCase multiple herbicide resistance evolved in a Lolium rigidum biotype. Planta 2007, 225, 499-513.

19. Owen, L.N.; Steckel, L.E.; Koger, C.H.; Main, C.L.; Mueller, T.C. Evaluation of spring and fall burndown application timings on control of glyphosate-resistant horseweed (Conyza canadensis) in no-till cotton. Weed Technol. 2009, 23, 335-339.

20. Steckel, L.E.; Craig, C.C.; Hayes, R.M. Glyphosate-resistant horseweed (Conyza canadensis) control with glufosinate prior to planting no-till cotton (Gossypium hirsutum). Weed Technol. 2006, 20, 1047-1051.

21. Steckel, L.E.; Gwathmey, C.O. Glyphosate-resistant horseweed (Conyza canadensis) growth, seed production, and interference in cotton. Weed Sci. 2009, 57, 346-350. 
22. Purba, E.; Preston, C.; Powles, S.B. The mechanism of resistance to paraquat is strongly temperature dependent in resistant Hordeum leporinum Link. and H. glaucum Steud. Planta 1995, $196,464-468$.

23. Kumaratilake, A.R.; Preston, C. Low temperature reduces glufosinate activity and translocation in wild radish (Raphanus raphanistrum). Weed Sci. 2005, 53, 10-16.

24. Putnam, A.R.; Ries, S.K. The synergistic action of herbicide combinations containing paraquat on Agropyron repens (L.) Beauv. Weed Res. 1967, 7, 191-199.

25. Colby, S.R.; Wojtazek, T.; Warren, G.F. Synergistic and antagonistic combinations for broadening herbicidal selectivity. Weeds 1965, 13, 87-91.

26. Griffin, J.L.; Miller, D.K.; Ellis, J.M.; and Clay, P.A. Sugarcane tolerance and Italian ryegrass (Lolium multiflorum) control with paraquat. Weed Technol. 2004, 18, 555-559.

27. Kapusta, G. Seedbed tillage and herbicide influence on soybean (Glycine max) weed control and yield. Weed Sci. 1979, 27, 520-526.

(C) 2012 by the authors; licensee MDPI, Basel, Switzerland. This article is an open access article distributed under the terms and conditions of the Creative Commons Attribution license (http://creativecommons.org/licenses/by/3.0/). 